\title{
PONDOK PESANTREN: LEMBAGA PENDIDIKAN PEMBENTUKAN KARAKTER
}

\author{
Imam Syafe'i \\ syafeiimam6@gmail.com \\ Universitas Islam Negeri Raden Intan Lampung
}

\begin{abstract}
Islamic Boarding Schools are the forerunner of Islamic education institutions in Indonesia. The initial attendance of Islamic boarding schools was estimated from 300-400 years ago and reached almost all levels of the Indonesian Muslim community, especially in Java. After Indonesia's independence, especially since the transition to the New Order and when economic growth really increased sharply, Islamic boarding school education became more structured and the pesantren curriculum became better. For example, in addition to the religious curriculum, pesantren also offer general lessons using a dual curriculum, mone curriculum and Ministry of Religion curriculum. As an educational institution, pesantren are very concerned about the field of religion (tafaqquh $f i$ al-din) and the formation of national character characterized by morality. The provisions of religious education are explained in the National Education Law Article 30 paragraph (4) that religious education is in the form of diniyah education, pesantren, and other similar forms. The existence of Islamic boarding schools is an ideal partner for government institutions to jointly improve the quality of education and the foundation of national character. This can be found from various phenomena that occur, such as fights between schools and distributors that are widespread and drug users among young people are rarely found they are boarding children or graduates of boarding schools.
\end{abstract}

Keywords: Islamic Boarding School; education; formation; character

\section{Abstrak}

Pondok Pesantren adalah cikal bakal institusi pendidikan Islam di Indonesia. Kehadiran awal pesantren diperkirakan dari 300-400 tahun yang lalu dan menjangkau hampir semua tingkat komunitas Muslim Indonesia, khususnya di Jawa. Setelah Indonesia merdeka, terutama sejak masa transisi ke Orde Baru dan ketika pertumbuhan ekonomi benar-benar meningkat tajam, pendidikan pesantren menjadi lebih terstruktur dan kurikulum pesantren menjadi lebih baik. Sebagai contoh, selain kurikulum agama, pesantren juga menawarkan pelajaran umum dengan menggunakan kurikulum ganda, kurikulum mone dan kurikulum Kemenag. Sebagai lembaga pendidikan, pesantren sangat peduli pada bidang agama (tafaqquh fi al-din) dan pembentukan karakter bangsa yang bercirikan akhlakul karimah. Ketentuan pendidikan agama dijelaskan dalam UU Sisidiknas Pasal 30 ayat (4) bahwa pendidikan agama dalam bentuk pendidikan diniyah, pesantren, dan bentuk-bentuk serupa lainnya. Keberadaan pesantren merupakan mitra ideal bagi institusi pemerintah untuk bersama-sama meningkatkan kualitas pendidikan dan landasan karakter bangsa. Hal ini dapat ditemukan dari berbagai fenomena yang terjadi seperti perkelahian antar sekolah dan distributor yang tersebar luas dan pengguna narkoba di kalangan anak muda jarang ditemukan mereka adalah anak-anak asrama atau lulusan dari pesantren.

Kata Kunci: Pondok Pesantren; pendidikan; pembentukan; karakter 


\section{PENDAHULUAN}

Pondok pesantren yang melembaga di masyarakat, terutama di pedesaan merupakan salah satu lembaga pendidikan Islam tertua di Indonesia. Awal kehadiran Boarding School bersifat tradisional untuk mendalami ilmu-ilmu agama Islam sebagai pedoman hidup (tafaqquh fi al-din) dalam bermasyarakat (Mastuhu, 1994). Karena keunikannya itu, C. Geertz demikian juga Abdurrahman Wahid menyebutnya sebagai subkultur masyarakat Indonesia (khususnya Jawa). Pada zaman penjajahan, pesantren menjadi basis perjuangan kaum nasionalis-pribumi.

Penyelenggaraan lembaga pendidikan pesantren berbentuk asrama yang merupakan komunitas tersendiri di bawah pimpinan kyai atau ulama dibantu oleh seorang atau beberapa or- ang ulama, dan atau para ustadz yang hidup bersama di tengah-tengah para santri dengan masjid atau surau sebagai pusat kegiatan peribadatan keagamaan. Di samping itu, gedung- gedung sekolah atau ruang- ruang belajar sebagai pusat kegiatan belajar mengajar, serta pondok-pondok sebagai tempat tinggal santri. Selama 24 jam, dari masa ke masa mereka hidup kolektif antara kyai, ustadz, santri dan para pengasuh pesantren lainnya, sebagai satu keluarga besar (Hayati, 2011).

Kiprah pesantren dalam berbagai hal sangat dirasakan oleh masyarakat. Contoh utama adalah pembentukan kader-kader ulama dan pengembangan keilmuan Islam, merupakan gerakan-gerakan protes terhadap pemerintah kolonial Hindia Belanda. Protes tersebut selalu dimotori dari dan oleh kaum santri. Setidaknya dapat disebutkan misalnya; pemberontakan petani di Cilegon-Banten 1888 (Kartodirjo, 1993). Jihad Aceh 1873 (Kartodirjo, 1993), gerakan yang dimotori oleh H. Ahmad Ripangi Kalisalak 1786-1875 dan yang lainnya merupakan fakta yang tidak dapat dibantah bahwa pesantren mempunyai peran yang cukup besar dalam perjalanan sejarah Islam di Indonesia (Steenbrink, 1994).

Isu mengenai pendidikan karakter merebak, berdasarkan berbagai peristiwa yang terjadi, bahwasanya moral anak bangsa telah merosot begitu tajamnya. Hal ini disebabkan antara lain karena banyak sekolah di Indonesia hanya menjadi tempat untuk memindahkan pengetahuan baik pengetahuan secara umum maupun etika, dan belum sampai pada taraf pembentukan moral dan etika (character building) (Faiqoh \& Mahfudh, 2015). 
Karakter merupakan nilai-nilai perilaku manusia yang berhubungan dengan Tuhan Yang Maha Esa, diri sendiri, sesama manusia, lingkungan, dan kebangsaan yang terwujud dalam pikiran, sikap, perasaan, perkataan, dan perbuatan berdasarkan normanorma agama, hukum, tata krama, budaya, dan adat istiadat (Samani \& Hariyanto, 2011; Subekti, 2015). Karakter dapat juga diartikan sama dengan akhlak dan budi pekerti, sehingga karakter bangsa identik dengan akhlak bangsa atau budi pekerti bangsa. Bangsa yang berkarakter adalah bangsa yang berakhlak dan berbudi pekerti, sebaliknya bangsa yang tidak berkarakter adalah bangsa yang tidak atau kurang berakhlak atau tidak memiliki standar norma dan perilaku yang baik (Asmaun Sahlan, 2013).

Pembentukan karakter harus dilakukan secara sistematis dan berkesinambungan yang melibatkan aspek knowledge, feeling, loving dan action. Pembentukan karakter dapat diibaratkan sebagai pembentukan seseorang menjadi body builder (binaragawan) yang memerlukan "latihan otot-otot akhlak" secara terus-menerus agar menjadi kokoh dan kuat (Asmaun Sahlan, 2013; Muslich, 2011).

Pengembangan aspek-aspek pendidikan karakter diutamakan pada karakterkarakter dasar yang menjadi landasan untuk berperilaku dari setiap individu. Indonesia Heritage Foundation merumuskan sembilan karakter dasar yang menjadi tujuan pendidikan karakter, antara lain : 1). Cinta kepada allah dan semesta beserta isinya, 2). Tanggung jawab, disiplin dan mandiri, 3). Jujur, 4). hormat dan santun, 5) Kasih sayang, peduli, dan kerja sama, 6). Percaya diri, kreatif, kerja keras dan pantang menyerah, 7) Keadilan dan kepemimpinan, 8) baik, rendah hati, dan 9). Toleransi, cinta damai dan persatuan (Purwanti, 2012).

Pendidikan sebagai upaya pembentukan karakter adalah bagian integral dari orientasi pendidikan Islam. Tujuannya adalah membentuk kepribadian seseorang agar berperilaku jujur, baik dan bertanggungjawab, menghormati dan menghargai orang lain, adil, tidak diskriminatif, egaliter, pekerja keras dan karakter- karakter unggul lainnya.

Menurut Megawangi dalam (Majid \& Andayani, 2011; Malik, R, \& S, 2013)Pendidikan karakter merupakan sebuah usaha untuk mendidik anak-anak agar dapat mengambil keputusan dengan bijak dan mempraktikanya dalam kehidupan seharihari sehingga mereka dapat memberikan kontribusi yang positif kepada lingkunganya.

Salah satu institusi pendidikan yang disinyalir telah lama menerapkan pendidikan karakter adalah pondok pesantren. Pondok Pesantren sebagai salah satu sub- 
sistem Pendidikan Nasional yang indigenous Indonesia, bahkan dipandang oleh banyak kalangan mempunyai keunggulan dan karakteristik khusus dalam mengaplikasikan pendidikan karakter bagi anak didiknya (santri). Pandangan demikian tampaknya berasal dari kenyataan bahwa: pesantren lebih mudah membentuk karakter santrinya karena institusi pendidikan ini menggunakan sistem asrama yang memungkinkannya untuk menerapkan nilai-nilai dan pandangan dunia yang dianutnya dalam kehidupan keseharian santri (Makmun, 2014). Telah banyak penelitian dilakukan berkaitan dengan pondok pesantren dan pendidikan karakter, diantaranya (Aulia \& Samino, 2015; Faiqoh \& Mahfudh, 2015; Kurniawan, 2016; Makmun, 2014; Nuryana, 2013; Rodliyah, 2014; Subekti, 2015; Sulaiman, 2013; Ubaidillah, 2016; Zuhriy, 2011)

Proses pengembangan dunia pesantren harus didukung oleh pemerintah secara serius sebagai proses pembangunan manusia seutuhnya. Meningkatkan dan mengembangkan peran pesantren dalam proses pembangunan di era otonomi daerah merupakan langkah strategis dalam upaya mewujudkan tujuan pembangunan nasional terutama sektor pendidikan. Terlebih, dalam kondisi bangsa yang tengah mengalami krisis (degradasi) moral. Pesantren sebagai lembaga pendidikan membentuk dan mengembangkan nilai-nilai moral menjadi pelopor sekaligus inspirator pembangkit moral bangsa..

Berdasarkan penjelasan uraian dan penelitian terdahulu, penulis akan membahas tentang (a) Sejarah pesantren dan perkembangannya,(b) pesantren antara harapan dan tantangan,(c) Fungsi dan Tujuan Pendidikan Pesantren(d) format pesantren masa depan.

\section{HASIL KAJIAN DAN PEMBAHASAN}

\section{Sejarah Pesantren dan Perkembangannya}

Pesantren sesungguhnya merupakan lembaga pendidikan tertua di Indonesia, yang secara nyata telah melahirkan banyak ulama'. Tidak sedikit tokoh Islam lahir dari lembaga pesantren. Bahkan Prof.Dr.Mukti Ali pernah mengatakan bahwa tidak pernah ada ulama yang lahir dari lembaga selain pesantren. Istilah "pesantren" berasal dari kata pe-"santri"-an, dimana kata "santri" berarti murid dalam bahasa Jawa. Istilah "pondok" berasal dari bahasa Arab "funduuq" ("'فندوق'") yang berarti penginapan. Khusus di Aceh, pesantren disebut juga dengan nama "dayah". Menurut laporan Van Bruinessen pesantren tertua di Jawa adalah pesantren Tegalsari yang didirikan tahun 1742, disini 
anak-anak muda dari pesisir utara belajar agama Islam. Namum hasil survey Belanda 1819, dalam Van Bruinessen lembaga yang mirip pesantren hanya ditemukan di Priangan, Pekalongan, Rembang, Kedu, Madiun, dan Surabaya (Bruinessen, 1995). Dari hasil penelusuran sejarah pula, ditemukan sejumlah bukti kuat yang menunjukkan bahwa cikal-bakal pendirian pesantren pada periode awal ini terdapat di daerah-daerah sepanjang pantai utara Jawa, seperti Giri (Gresik), Ampel Denta (Surabaya), Bonang (Tuban) Kudus, Lasem, Cirebon, dan sebagainya. Kota-kota tersebut pada waktu itu merupakan kota cosmopolitan yang menjadi jalur penghubung perdagangan dunia, sekaligus tempat persinggahan para pedagang dan muballigh Islam yang datang dari Jazirah Arabiah seperti Hadramaut, Persia, Irak dan lain sebagainya (Makmun, 2014). Mastuhu memberikan kesimpulan lain, bahwa pesantren di Nusantara telah ada sejak abad ke 13-17, dan di Jawa sejak abad 15-16 M bersamaan dengan masuknya Islam di Indonesia (Mastuhu, 1994). Laporan mastuhu dikuatkan oleh Dhafier bahwa dalam serat Senthini dijelaskan pada abad 16 telah banyak pesantren-pesantren mashur di Indonesia yang menjadi pusat pendidikan Islam (Dhofier, 1982). Akan tetapi, laporan Mastuhu dan Dhofier di tolak oleh Van Bruinessen, dimana serat Senthini tersebut disusun abad 19, oleh karena itu tidak bisa dianggap sebagai sumber yang dapat dipercaya untuk menjelaskan kejadian abad 17 M (Bruinessen, 1995). Oleh karena itu para sejarahwan menyimpulkan bahwa lembaga pendidikan keIslam di Indonesia belum ada sebelum abad $18 \mathrm{M}$ dan baru muncul pada akhir abad $18 \mathrm{M}$ dan awal $19 \mathrm{M}$ (Bruinessen, 1995).

Biasanya pesantren dipimpin oleh kyai. Untuk mengatur kehidupan pesantren, kyai menunjuk seorang santri senior untuk mengatur adik-adik kelasnya, mereka biasanya dalam pesantren salaf (tradisional) disebut "lurah pondok". Tujuan santri dipisahkan dari orang tua dan keluarga mereka agar mereka belajar hidup mandiri, dapat meningkatkan hubungan yang baik dengan kyai dan juga Tuhan. Ada beberapa elemen pesantren yang membedakan dengan lembaga lainnya, yaitu; (1) pondok tempat menginap para santri, (2) santri: peserta didik, (3) masjid: sarana ibadah dan pusat kegiatan pesantren, (4) kyai: tokoh atau sebutan seseorang yang memiliki kelebihan dari sisi agama, dan kharisma yang dimilikinya, (5) kitab kuning: sebagai referensi pokok dalam kajian keislaman (Dhofier, 1982). Awal munculnya pesantren, pembelajarannya bersifat nonklasikal, dimana seorang kyai mengajarkan agama Islam yang ditulis pada abad pertengahan (Prasidjo \& Al, 2001). Meskipun kajian-kajian tersebut banyak 
mengungkap fikih, tafsir dan bahasa arab untuk membedah ilmu-ilmu agama. Fikih yang banyak dikaji pada umumnya adalah yang bernuansa mazhab Syafii dengan sedikit menerima mazhab yang lain, kemudian ajaran-ajaran akhlak dan tasawufnya lebih bercorak tasawuf al-Ghazali, meskipun banyak tokoh sufi atau ajaran-ajaran tasawuf yang lain (Bruinessen, 1995). Oleh karena itu, pesantren menurut pandangan Azumardi Azra masih sangat minim mengkaji tasawauf secara mendalam, tasawuf yang dikaji hanya sebatas tasawuf Al-Ghazali dan As-Ariyyah.

Pesantren, dilihat dari sejarah, sosiologis dan antropologis, lembaga ini seharusnya dipandang sebagai lembaga pendidikan alternatif di Indonesia, namun pemerintah terkesan melihat sebelah mata dengan lembaga pendidikan formal lainnya. Di satu sisi pemerintah mengakui produk-produk atau kualitas lulusan pesantren akan tetapi disisi lain pesantren tetap tidak secara utuh diakui sebagai lembaga pendidikan. Pesantren memiliki ciri-ciri khas yang berbeda dari lembaga pendidikan pada umumnya. Ciri khas yang disandang itu menjadikan tidak akan mungkin pesantren diberlakukan peraturan yang sama dengan sekolah. Penyelenggaraan pendidikan di pesantren salaf umumnya dengan menggunakan metode sorogan, bandungan, dan wetonan. Sistem sorogan merupakan proses pembelajaran yang bersifat individual atau pendidikan tradisional, dan sistem pembelajaran dasar dan paling sulit bagi para santri, sebab santri dituntut kesabaran, kerajinan, ketaatan dan disiplin diri dalam menuntut ilmu. Seringkali santri tidak menyadari bahwa mereka seharusnya mematangkan diri pada tingkat sorogan ini sebelum mengikuti sistem pembelajaran selanjutnya. Seorang santri yang telah mahir dalam penguasaan sorogan ini menjadi kunci dalam penguasaan ilmu agama dan menjadi seorang alim. Sedangkan sistem bandungan atau juga disebut wetonan yaitu sistem belajar kelompok dalam arahan dan bimbingan kyai yang terdiri antara 5 sampai 500 orang santri. Mereka mendengarkan seorang guru atau kyai yang membaca, menerjemahkan, menerangkan, dan mengulas kitab-kitab dalam bahasa arab dan santri masing-masing memperhatikan bukunya sendiri dan membuat catatan-catatan yang dianggap sulit atau penting. Kelompok sistem ini disebut halaqah. Jika kyai berhalangan untuk memberikan pengajaran dalam sistem ini, biasanya kyai menunjuk santri senior mewakilinya atau disebut ustadz. Dalam sistem sorogan ini juga terjadi musyawarah atau diskusi tentang kajian Islam klasik dengan sumber kitab yang jelas. Bahan diskusi dan hasil diskusi selalu dihadapkan ke kyai untuk dikoreksi dan 
penguatan apabila hasil diskusi tidak menyimpang dan sudah sesuai dengan teks-teks kitab klasik. Metode ini diberikan untuk melatih dan menguji kematangan mental santri, agar kelak kemudian menjadi orang yang tangguh dalam beragama atau menjadi ulama yang warasatul anbiya (Dhofier, 1982). Sedangkan pesantren khalaf manejemen pesantren dan kurikulum pesantren semuanya adalah sistem modern. Kyai tidak lagi mengurus keuangan pesantren, melainkan bendahara pesantren. Kurikulum yang ada dengan pola kurikulum modern dengan sistem pembelajaran klasikal (Zarkasyi, 1998). Tampak perbedaan bahwa pesantren khalaf sistem administrasi,menejemen, dan tata kelola lembaga lebih terbuka dibandingkan sistem pesantren salaf yakni sistem menejemen, dan keuangan pesantren selalu dalam kendali otoritas kyai, meski telah dibantu oleh lurah pondok sebagai pengendali operasionalnya, namun pelaksanaannya tetap mengacu kepada restu kyai, atau dengan kata lain sistem pesantren salaf, semuanya masih serba kyai, semua oleh kyai, duitnya kyai, utangnya juga kyai yang menanggung, santri tidak bayar juga urusan kyai dan sebagainya.

Pada abad ke 19 Masehi, muncul pengaruh wahabiyah di Indonesia. Sebagai akibat dari pengaruh ini, di Minangkabau terjadi peperangan antara kaum paderi dengan kaum adat. Belanda mengambil kesempatan dengan adanya peperangan ini dan berpihak kepada kaum adat. Sementara itu, di jawa berdiri beberapa organisasi seperti Muhammadiyah dan Persis. Seiring perkembangan Islam di Nusantara corak tersebut secara pelan mengalami pergeseran. Menurut survei yang diselenggarakan kantor Shumubu berdasarkan catatan kantor Urusan Agama yang dibentuk oleh Pemerintah Militer Jepang tahun 1942 dalam Dhofier jumlah elemen-elemen pesantren di Jawa sebagaimana dilihat dalam tabel berikut.

Tabel 1.1 Jumlah Elemen-Elemen Pesantren di Jawa

\begin{tabular}{|l|l|l|l|l|l|l|}
\hline No & Elemen Pesantren & Jakarta & Jawa Barat & $\begin{array}{l}\text { Jawa } \\
\text { Tengah }\end{array}$ & $\begin{array}{l}\text { Jawa } \\
\text { Timur }\end{array}$ & Jumlah \\
\hline 1 & Pesantren/Madrasah & 167 & 1.046 & 351 & 307 & 1.871 \\
\hline 2 & Kyai & & $\begin{array}{l}7.652(\text { Dhafier: } \\
1982: 40)\end{array}$ & 4.466 & 6.150 & 18.268 \\
\hline 3 & Santri/murid & 14.513 & 69.954 & 21.957 & 32.931 & 139.415 \\
\hline
\end{tabular}


Jumlah angka-angka ini terus mengalami pertumbuhan, menurut laporan resmi Departemen Agama tahun 1978 dengan data pesantren tahun 1977, jumlah lembagalembaga pesantren di Jawa dan Madura sebanyak 3.195, dan jumlah murid sebanyak 677. 384 (Dhofier, 1982). Kemudian tahun 1982 menurut catatan Departemen Agama RI jumlah pesantren diseluruh Indonesia 4.980 dengan 735.417 santri (Azra, 1997). Mengalami peningkatan yang cukup luar biasa sebagaimana dikutip Masyhud pada tahun 1985, di mana pesantren berjumlah sekitar 6.239 dengan jumlah santri sekitar 1.084.801 orang. Kebanyakan dari jumlah pesantren tersebut adalah pesantren shalafi. Baik pesantren khalafi maupun salafi kecuali Gontor menurut Dhofier, tetap mempertahankan elemen-elemen pesantren sebagai ciri khas pendidikan Islam Indonesia.

Pembaharuan penting yang terjadi di pesantren menurut Dhofier terjadi pada tahun 1910, pesantren Denanyar di Jombang, telah membuka murid-murid untuk wanita. Tahun 1920-an pesantren Tebuireng Jombang dan pesantren Singosari di Malang, mulai mengajarkan pelajaran umum, seperti; bahasa Indonesia, berhitung, ilmu bumi, dan sejarah, tampaknya sudah mulai adanya sistem klasikal di pesantren. Selanjutnya awal abad 20 misalnya, Gontor mempelopori berdirinya pesantren yang menekankan aspek kaderisasi pendidikan Islamd an menejemen terbuka (open menegement). Pesantren ini santri dibekali dasar-dasar ilmu agama dan berbagai ketrampilan hidup sehingga kelak ia bisa berwirausaha dan membina masyarakat. Metode pengajaran dimodernisasi sedemikian rupa. Dibukanya sistem madrasah di pesantren sejak abad 20-an, merupakan salah satu ciri menghilangnya santri kelana dan diterapkannya sistem klasikal merubah pandangan santri terhadap ketergantungan kepada ijazah formal sebagai hasil belajarnya. Meskipun pesantren telah mengalami perubahan, tetapi jumlahnya masih sangat terbatas dibandingkan dengan sekolah umum. Menurut Dhafier ada dua alasan mengapa pesantren lambang mengadakan perubahan, pertama kyai masih mempertahankan dasar-dasar tujuan pendidikan pesantren, yaitu untuk menyebarkan dan mempertahankan Islam. Kedua, belum memiliki tenaga ahli sesuai dengan kebutuhan yang diperlukan (Dhofier, 1982). Ada faktor lain yang menjadikan tetap survive-nya pesantren, seperti; (1) menjadi alternatif bagi calon siswa dan mahasiswa yang gagal PSB masuk dalam sekolah umum atau UMPTN/ PMB, (2) tradisi pesantren yang merakyat/tidak elitis sebagai modal berharga bagi pengembangan 
pendidikan pesantren yang humanis, (3) keampuhan pesantren sebagai benteng kultur dan agama bagi generasi muda, dan (4) memiliki ikatan dan keakraban yang kuat dengan dengan masyarakat sekitarnya (Azra, 1997).

Sekarang ini banyak ditemukan model-model pesantren di Indonesia yang nyaris berbeda desain bangunannya dengan pesantren-pesantren klasik. Menurut Manfred Ziemek, maka tipe-tipe persantren di Indonesia dapat digolongkan sebagai berikut.

1. Tipe A, yaitu pondok pesantren yang seluruhnya dilaksanakan secara tradisional, dalam arti tidak mengalami transformasi yang berarti dalam sistem pendidikannya atau tidak ada inovasi yang menonjol dalam corak pesantrennya dan masih tetap eksis mempertahankan tradisi-tradisi pesantren klasik dengan corak keislamannnya berdasarkan peraturan menteri Agama Nomor 3 Tahun 1979 tentang Bantuan kepada Pondok Pesantren dalam (Makmun, 2014). Masjid digunakan untuk pembelajaran Agama Islam disamping tempat shalat. Tipe ini biasanya digunakan oleh kelompok-kelompok tarikat dan disebut pesantren tarikat. Para santri pada umumnya tinggal di asrama yang terletak di sekitar rumah kyai atau di rumah kyai. Tipe ini sarana fisiknya terdiri dari masjid dan rumah kyai, pada umumnya dijumpai awal-awal berdirinya pesantren (Ziemek, 1986).

2. Tipe B, pesantren yaitu yang mempuyai sarana fisik, seperti; masjid, rumah kyai, pondok atau asrama yang disediakan bagi para santri, utamanya adalah dari daerah jauh, sekaligus menjadi ruangan belajar. Tipe ini adalah pesantren tradisional yang sangat sederhana sekaligus merupakan ciri pesantren tradisional (Ziemek, 1986). Sistem pembelajaran pada tipe ini adalah individual (sorogan), bandungan, dan wetonan.

3. Tipe $\mathrm{C}$, atau pesantren salafi ditambah dengan lembaga sekolah (madrasah, SMU atau kejuruan) merupakan karakteristik pembaharuan dan modernisasi pendidikan Islam di pesantren. Meskipun demikian, pesantren tidak menghilangkan sistem pembelajaran yang asli yaitu sistem sorogan, bandungan, dan wetonan yang dilakukan oleh kyai atau ustadz (Prasidjo \& Al, 2001).

4. Tipe D, yaitu pesantren modern terbuka untuk umum, corak pesantren ini telah mengalami transformasi yang sangat signifikan baik dalam sistem pendidikanmaupun unsur-unsur kelembagaannya. Materi dan sistem 
pembelajaran sudah menggunakan sistem modern dan klasikal. Jenjang pendidikan yang diselenggarakan mulai dari tingkat dasar (PAUD dan TK) sampai pada perguruan tinggi. Tipe ini sangat memperhatikan terhadap mengembangkan bakat dan minat santri sehingga santri bisa mengeksplor diri sesuai bakat dan minat (Nizar, 2007). Hal yang tidak kalah penting adalah keseriusan dalam penguasaan bahasa asing, baik bahsaa Arab dan Inggris maupun bahasa internasional lainnya. Contohnya, pesantren Gontor, Tebuireng dan pesantren modern lainnya yang ada di tanah air.

5. Tipe E, yaitu pesantren yang tidak memiliki lembaga pendidikan formal, tetapi memberikan kesempatan kepada santri untuk belajar pada jenjang pendidikan formal di luar pesantren. Pesantren tipe ini,dapat dijumlai pada pesantren salafi dan jumlahnya di nusantara relatif lebih kecil dibandingkan tipe-tipe lainnya.

6. Tipe $\mathrm{F}$, atau ma'had 'Aly, tipe ini, biasanya ada pada perguruan tinggi agama atau perguruan tinggi bercorak agama. Para mahasiswa di asramakan dalam waktu tertentu dengan peraturan-peraturan yang telah ditetapkan oleh perguruaan tinggi,m ahasiswa wajib mentaati peraturan-peraturan tersebut bagi mahasiswa yang tinggal di asrama atau ma'had. Sebagai contoh, ma'had 'aly UIN Malang yang telah ada sejak tahun 2000 dan semua mahasiswa wajib diasramakan selama satu tahun. Kemudian ma'had 'aly IAIN Raden Intan Lampung yang telah berdiri sejak 2010 yang lalu. Tujuan dari ma'had 'aly tersebut adalah untuk memberikan pendalaman spiritual mahasiswa dan menciptakan iklim kampus yang kondusif untuk pengembangan bahasa asing ("Visi, Misi dan Tradisi UIN Maulana Malik Ibrahim Malang," 2012).

Melihat keaneka ragaman pesantren tersebut diatas, maka Abdullah Syukri Zarkasyi berpendapat bahwa pesantren sejak berdirinya hingga perkembangannya dewasa ini, pesantren dapat dikategorikan menjadi tiga macam bentuk, yaitu: Pertama, pesantren tradisional yang masih tetap mempertahankan tradisi-tradisi lama, pembelajaran kitab, sampai kepada permasalahan tidur, makan dan MCK-nya, serta kitab-kitab maraji'-nya biasa disebut kitab kuning (Zarkasyi, 1998). Kedua, pesantren semi modern, yaitu pesantren yang memadukan antara pesantren tradisional dan pesantren modern. Sistem pembelajaran disamping kurikulum pesantren tradisional dalam kajian kitab klasik juga menggunakan kurikulum Kemenag dan kemendiknas. 
Ketiga, pesantren modernyang kurikulum dan sistem pembelajarannya sudah tersusun secara modern demikian juga menejemennya. Disamping itu, menurut Zarkasyi pesantren modern sudah didukung IT dan lembaga bahasa asing yang memadai (Zarkasyi, 1998). Termasuk ma'had 'aly dikategorkanbentuk pesantren modern.

\section{Fungsi dan Tujuan Pendidikan Pesantren}

Fungsi pesantren tidak semata-mata hanya sebagai lembaga pendidikan tafaqquh fi al-dien an sich, tetapi multi komplek yang menjadi tugas pesantren. Pendidikan di pesantren tidak berhenti sebagai aktifitas transfer ilmu saja. Hal senada juga dikemukakan oleh Tholkhah Hasan mantan menteri agama RI, bahwa pesantren seharusnya mampu menghidupkan fungsi-fungsi sebagai berikut, 1) pesantren sebagai lembaga pendidikan yang melakukan transfer ilmu-ilmu agama (tafaqquh fi al-din) dan nilai-nilai Islam (Islamic vaues); 2) pesantren sebagai lembaga keagamaan yang melakukan kontrol sosial; dan 3) pesantren sebagai lembaga keagamaan yang melakukan rekayasa sosial (social engineering) atau perkembangan masyarakat (community development). Semua itu, menurutnya hanya bisa dilakukan jika pesantren mampu melakukan proses perawatan tradisi-tradisi yang baik dan sekaligus mengadaptasi perkembangan keilmuan baru yang lebih baik, sehingga mampu memainkan peranan sebagai agent of change (Wahidah, 2015).

Pesantren sebagai lembaga sosial dan penyiaran keagamaan. Hampir kita temukan masyarakat di sekitar pesantren relatif lebih bagus dibandingkan masyarakat yang jauh dari pesantren. Hal ini tidak terlepas dari peran pesantren membangun masyarakat melalui pesan-pesan agama. Jaringan (network) pesantren kepada masyarakat lebih dititik beratkan kepada ikatan orang tua, santri dengan pesantren, atau jaringan thariqah yang ada pada pesantren tertentu. Jaringan thariqah ini biasanya memiliki hubungan lebih kuat dengan pesantren ketimbang hanya hubungan orang tua santri pada umumnya. Sebagai lembaga pendidikan, pesantren menyelenggarakan pendidikan sekolah, (madrasah, sekolah umum, kejuruan, dan perguruan tinggi) serta pendidikan luar sekolah berupa kursus-kursus keahlian (life skill), untuk menunjang kehidupan santri pasca mengikuti pendidikan pesantren, karena pesantren tidak mencetak santrinya untuk menjadi pegawai pemerintah (PNS), tetapi lebih menitik beratkan kepada kemandirian santri yang tidak mengekor atau menjadi beban orang/lembaga lain. 
Karena itu, pesantren selalu membekali pendidikan kewirausahaan santrinya sesuai dengan bentuk life skill yang diberikan oleh masing-masing pesantren.

Proses rekrutmen santri, juga beraneka ragam. Ini menunjukan bahwa pesantren adalah lembaga untuk semua. Menurut Nizar sebagai lembaga pendidikan dan sosial, pesantren tidak pernah membeda-bedakan status sosial bagi calon santri maupun tamu yang dating (Nizar, 2007). Menurut (Suryanegara, 1998), pesantren juga memiliki peran yang sangat besar dalam merespon ekspansi politik kolonial Belanda. Semangat juang dalam mengusir kaum penjajah di tanah air lebih banyak dikibarkan dari pesantren atau kaum santri dengan semangat jihad dan hubb-u al-wathan min al-imanmereka berani mati melawan penjajah.

\section{Pesantren Antara Harapan dan Tantangan}

Ketangguhan pesantren dalam mempertahankan misinya sebagai lembaga bukan berarti tidak mengalami hambatan. Tantangan yang dihadapi pesantren pertama kali muncul, ketika bangsa Indonesia mengalami penindasan kaum penjajah (Damopolii, 2011). Perjanjian Gianti yang terjadi pada 1825 pemerintah Belanda membatasi jumlah calon jama'ah haji Indonesia dan melakukan hubungan multilateral dengan negaranegara Islam lainnya, pesantren dicap sebagai basis perlawanan terhadap bangsa asing (Hindia Belanda). Oleh karena itu, sebagai respon atas penindasan belanda, kaum santri pun mengadakan perlawanan. Menurut Clifford Geertz, antara 1820-1880 M, telah terjadi pemberontakan besar yang dimotori oleh kaum santri di Indonesia, antara lain; 1) Pemberontakan kaum padri di sumatra dipimpin oleh Imam Bonjol, 2) Pemberontakan Diponegoro di Jawa, 3) Pemberontakan Banten akibat aksi tanam paksa yg dilakukan belanda, 4) Pemberontakan di Aceh yg dipimpin antara lain oleh Teuku Umar dan Teuku Ciktidiro.

Pada era Soekarno, pesantren harus berhadapan dengan kaum komunis. Banyak sekali pertikaian ditingkat bawah yg melibatkan kalangan santri dan kaum komunis. Agaknya hal ini memang sengaja direncanakan secara sistematis untuk menjauhkan orang-orang Islam dari struktur pemerintahan guna melanggengkan ideologi sekuler.

Meskipun mendapat tekanan dari pihak pemerintah, pesantren pada kedua orde tersebut tetap mampu menelorkan orang-orang hebat yang menjadi orang-orang penting di negara kita seperti KH Wahid Hasyim, M Nastir, Buya Hamka, Mukti Ali, KH 
Saifuddin Zuhri dll. Mulai tahun 1970-an dan diakhir tumbangnya orde baruyang dimana ekonomi Indonesia mulai ambruk, pesantren tampak kembali dengan supremasinya karena adanya program-program baru yang digulirkan oleh pemerintah yaitu ekonomi kerakyatan. Pihak pemerintah berupaya menggandeng pesantren sebagai mitra dalam pengentaskan kemiskinan dan mengembangkan ekonomi kerakyatan (Proyek Pembangunan Pertanian Rakyat Terpadu Biro Perencanaan, Departemen Pertanian, 1998). Di jadikannya pesantren sebagai agen pembangunan yang berorientasi kerakyatan karena pesantren dianggap satu-satunya lembaga yang eksis dan dipercaya untuk penyaluran dana-dana ekonomi kerakyatan serta memiliki akar bawah yang sangat kuat dan sikap mentalitas yang bisa dipertanggung jawabkan. Tawaran ini ditanggapi dengan serius dan diterima oleh pesantren (Kuntowijoyo, 1993). Sehingga tidak heran saat itu banyak pesantren yang mendapat hadiah kalpatarudari pemerintah Suharto, karena peran pesantren dalam pengembangan ekonomi umat juga pesantren menjadi mitra ekonomi kerakyatan pemerintah.

Gerakan globalisasi dan modernisasi adalah dua sisi dari satu mata uangjuga telah masuk pada bilik-bilik pesantren.Ini memberikan ujian yang cukup luar biasa bagi pesantren. Satu sisi pesantren harus mempertahankan tradisi kepesantrenannya sebagai lembaga "asli" atau "indigenous" Indonesia (Madjid, 1997), tetapi disisi lain pesantren tidak bisa menghindar dari globalisasi dan modernisasi dengan segala produk yang ditawarkan. Ia menawarkan sebuah pilihan yang ambivalen, satu sisi membawa kebaikan, dan mungkin juga membawa petaka bila tidak siap menghadapinya. Globalisasi adalah sebuah keniscayaan yang nyata yang mau tak mau akan kita hadapi bersama. Menghadapi tantangan ini pesantren dituntut untuk bertindak bijak. Kalau serta merta menolak globalisasi dengan melestarikan konstruksi lama dan tidak mau melihat sesuatu yang baru akan merugikan pesantren di kemudian hari, karena orang modern sebagai mana disebutkan di atas lebih mementingkan nilai-nilai instrumental, akhir-akhir ini pesantren telah membuka diri. Jika dahulu pesantren hanya sebagai tempat mengaji ilmu agama melalui sistem sorogan, wetonan, dan bandungan, maka saat ini telah membuka pendidikan sistem klasikal dan bahkan program baru yang berwajah modern dan formal seperti madrasah, sekolah, dan bahkan universitas. Sekalipun pendidikan modern telah masuk ke pesantren, akan tetapi tidak boleh menggeser tradisinya, yakni gaya kepesantrenan. Sebaliknya, kehadiran lembaga 
pendidikan formal dalam pesantren dimaksudkan untuk memperkokoh tradisi yang sudah ada, yaitu pendidikan model pesantren. Adaptasi adalah suatu bentuk keniscayaan tanpa menghilangkan ciri khas yang dimiliki pesantren (al-muhâfazhah `ala al-qadîm as-shâlih wa al-akhdzu bi al-jadîd al-ashlah). Pendidikan pesantren sejak awal memang bukan dimaksudkan untuk menyiapkan tenaga kerja terampil pada sektor-sektor modern sebagaimana diangankan sekolah dan universitas pada umumnya. Melainkan diorientasikan kepada bagaimana para santri dapat memahami, menghayati, dan mengamalkan ajaran Islam secara baik. Pendidikan pesantren adalah pendidikan Islam yang berusaha mengantarkan para santri menjadi alim dan shalih, bukan menjadi pegawai atau pejabat.

Dalam perkembangannya ke depan, yang harus selalu diingat adalah pesantren harus tetap menjadi "rumah" dalam mengembangkan pertahanan mental spiritual sesuai dengan perkembangan zaman. Selain itu, ilmu yang diajarkan di pesantren harus memiliki pola perpaduan (umum-agama) yang dilandasi karakteristik keilmuan Islam melalui kajian ayat-ayat qauliyah dan qauniyah, yang bersumber dari Allah SWT, untuk memenuhi kebutuhan yang bersifat duniawi dan ukhrawi, berlaku umum untuk semua komunitas manusia, realistis, dan terpadu (integral); artinya tidak membedabedakan pada dimensi keilmuannya, serta universal sehingga dapat melahirkan konsepkonsep keilmuwan di segala bidang dan semua kebutuhan manusia. Dan, yang tak kalah pentingnya adalah pesantren yang merupakan pendidikan berbasis agama (Islam), harus mampu memaksimalkan aspek da'wah karena da'wah merupakan bagian dari Islam dan tidak bisa dipisahkan dengan ilmu-ilmu keislaman.

\section{Format Pesantren Masa Depan.}

Sudah tidak diragukan lagi bahwa pesantren memiliki kontribusi nyata dalam pembangunan pendidikan. Apalagi dilihat secara historis, pesantren memiliki pengalaman yang luar biasa dalam membina dan mengembangkan masyarakat. Bahkan, pesantren mampu meningkatkan perannya secara mandiri dengan menggali potensi yang dimiliki masyarakat di sekelilingnya.Pembangunan manusia, tidak hanya menjadi tanggung jawab pemerintah atau masyarakat semata-mata, tetapi menjadi tanggung jawab semua komponen, termasuk dunia pesantren. Pesantren yang telah memiliki nilai historis dalam membina dan membangun masyarakat, kualitasnya harus terus didorong 
dan dikembangkan. Proses pembangunan manusia yang dilakukan pesantren tidak bisa dipisahkan dari proses pembangunan manusia yang tengah diupayakan pemerintah.

Proses pengembangan dunia pesantren yang selain menjadi tanggung jawab internal pesantren, juga harus didukung oleh pemerintah secara serius sebagai proses pembangunan manusia seutuhnya. Meningkatkan dan mengembangkan peran serta pesantren dalam proses pembangunan merupakan langkah strategis dalam membangun mewujudkan tujuan pembangunan nasional terutama sektor pendidikan. Terlebih, dalam kondisi yang tengah mengalami krisis (degradasi) moral. Pesantren sebagai lembaga pendidikan yang membentuk dan mengembangkan nilai-nilai moral, dengan basic agama harus menjadi pelopor sekaligus inspirator pembangunan moral bangsa. Sehingga, pembangunan tidak menjadi hampa melainkan lebih bernilai dan bermakna.

Pesantren pada umumnya bersifat mandiri, tidak tergantung kepada pemerintah atau kekuasaan yang ada. Karena sifat mandirinya itu, pesantren bisa memegang teguh kemurnian Pesantren. Karena itu, pesantren tidak mudah disusupi oleh ajaran-ajaran yang tidak sesuai dengan ajaran Islam.Sekalipun belakangan issu terorisme dienduskan dari kalangan pesantren, sebenarnya faham semacam itu tidak pernah diajarkan di lembaga pesantren. Pendidikan di pesantren yang merupakan bagian dari Sistem Pendidikan Nasional memiliki 3 unsur utama yaitu: 1) Kyai sebagai pendidik sekaligus pemilik pondok dan para santri; 2) Kurikulum pondok pesantren; dan 3) Sarana peribadatan dan pendidikan, seperti masjid, rumah kyai, dan pondok, serta sebagian madrasah dan bengkel-bengkel kerja keterampilan. Kegiatannya terangkum dalam "Tri Dharma Pondok pesantren" yaitu: 1) Keimanan dan ketaqwaan kepada Allah SWT; 2) Pengembangan keilmuan yang bermanfaat; dan 3) Pengabdian kepada agama, masyarakat, dan negara.

Agaknya perlu dicermati, bahwa pemaknaan pesantren masa lalu perlu ditinjau kembali atau perlu redefinisi dan reinterprestasi. Pesantren pada masa lalu yang dipahami sebuah asrama pendidikan Islam tradisional dimana santrinya tinggal bersama dan belajar dibawah bimbingan seorang (atau lebih) guru yang dikenal dengan sebutan kyai (Zarkasyi, 1998). Pondok atau asrama para santri pada masa lalu biasanya berupa bangunan yang terbuat dari bambu,atau bangunan tempat tinggal yang berpetak-petak yang berdinding bilik dan beratap rumbia (Steenbrink, 1994). Berangkat dari kenyataan, jelas pesantren di masa yang akan datang dituntut berbenah, menata diri dalam 
mengahadapi persaingan bisnis pendidikan seperti yang telah dilakukan oleh Muhammadiyah dan lainnya. Tapi perubahan dan pembenahan yang dimaksud hanya sebatas menejemen dan bukan coraknya apalagi berganti baju dari salafiyah ke mu'asyir (modern), karena hal itu hanya akan menghancurkan nilai-nilai positif pesantren seperti yang terjadi sekarang ini, lulusannya ora iso ngaji. Maka, idealnya pesantren ke depan harus bisa mengimbangi tuntutan zaman dengan mempertahankan tradisi dan nilai-nilai kesalafiannya. Pengkajian kitab kuning sebagai ciri khas pendidikan pesantren sepatutnya diajarkan sejak jenjang Ibtidaiyah sampai Aliyah sebagai KBM wajib santri dan mengimbanginya dengan pengajian tambahan, kegiatan extra seperti kursus komputer, bahasa inggris, skill lainnya dan program paket A, B dan C untuk mendapatkan Ijazah formalnya. Atau dengan menjalin kerjasama dengan sekolah lain untuk mengikuti persamaan. Jika hal ini terjadi, akan lahirlah ustadz-ustadz, ulama dan fuqoha yang mumpuni.

Ada dua fenomena menarik dalam pendidikan di Indonesia yakni (a) munculnya sekolah-sekolah terpadu (mulai tingkat dasar hingga menengah); (b) penyelenggaraan sekolah bermutu yang sering disebut dengan boarding school. Nama lain dari istilah boarding school adalah sekolah berasrama. Para murid mengikuti pendidikan reguler dari pagi hingga siang di sekolah, kemudian dilanjutkan dengan pendidikan agama atau pendidikan nilai-nilai khusus di malam hari. Selama 24 jam anak didik berada di bawah didikan dan pengawasan para guru pembimbing. Tanpa disadari, sesungguhnya sekolahsekolah itu merusaha meniru pola pendidikan pesantren, yang ternyata lulusan pesantren tidak kalah mutunya dengan lulusan sekolah-sekolah umum. Di sisi lain, sistem pesantren ternyata lebih unggul dalam membentuk kepribadian (UU Sisdiknas No 20 Tahun 2003: 2009: 101) santri, hal ini dibuktikan hingga sekarang belum ditemukan kasus santri tawuran antar santri atau pesantren, demikian juga dengan sekolah-sekolah umum. Sementara itu, tawuran antar pelajar pada sekolah-sekolah umum seakan-akan menjadi tontonan masyarakat. Kekuatan pesantren dalam membentuk kepribadian santri sebagaimana telah dikemukakan, tidak terlepas dari sistem boarding school yang telah lama diterapkan dalam pendidikan pesantren. Mereka dipacu menguasai ilmu dan teknologi secara intensif. Selama di lingkungan asrama mereka ditempa menerapkan ajaran agama, mengekspresikan seni budaya dan ketrampilan lainnya di hari libur. Harihari mereka adalah hari-hari berinteraksi dengan teman sebaya dan para guru. Rutinitas 
kegiatan dari pagi hari hingga malam sampai ketemu pagi lagi, mereka menghadapi makhluk hidup yang sama, orang yang sama, lingkungan yang sama, dinamika dan romantika yang sama pula. Dalam khazanah pendidikan kita, sekolah berasrama adalah model pendidikan yang cukup tua (Azra, 1997).

Secara tradisional jejak boarding school dapat kita selami dinamika kehidupan pesantren, pendidikan gereja, bahkan di bangsal-bangsal tentara. Pendidikan berasrama telah banyak melahirkan tokoh besar dan mengukir sejarah kehidupan umat manusia. Kehadiran boarding school adalah suatu keniscayaan zaman kini. Keberadaannya menadi suatu konsekwensi logis dari perubahan lingkungan sosial dan keadaan ekonomi serta cara pandang religiusitas masyarakat. Ada tiga alasan mengapa perlu boarding school, yaitu:

1. Lingkungan sosial telah banyak berubah terutama di kota-kota besar. Sebagian besar penduduk tidak lagi tinggal dalam suasana masyarakat yang homogen, kebiasaan lama bertempat tinggal dengan keluarga besar atau marga telah lama bergeser kearah masyarakat yang heterogen, majemuk, dan plural. Hal ini berimbas pada pola perilaku masyarakat yang berbeda karena dalam pengaruh nilai-nilai yang berbeda pula. Oleh karena itu sebagian masyarakat yang terdidik dengan baik menganggap bahwa lingkungan sosial seperti itu sudah tidak lagi kondusif bagi pertumbuhan dan perkembangan intelektual dan moralitas anak.

2. Keadaan ekonomi masyarakat yang membaik mendorong pemenuhan kebutuhan di atas kebutuhan dasar seperti kesehatan dan pendidikan. Bagi kalangan menengah atas yang baru muncul akibat tingkat pendidikan mereka yang tinggi sehingga mendapatkan posisi yang baik dalam lapangan pekerjaan berimplikasi pada tingginya penghasilan mereka. Hal ini mendorong niat untuk memberikan pendidikan yang terbaik bagi anak-anak melebihi pendidikan yang telah diterima orang tuanya.

3. Cara pandang religiusitas. Kecenderungan terbaru masyarakat perkotaan sedang bergerak kearah yang semakin religius. Indikatornya adalah semakin diminati dan semaraknya kajian dan berbagai kegiatan keagamaan. Modernitas membawa implikasi negatif dengan adanya ketidakseimbangan antara kebutuhan ruhani dan jasmani. Untuk itu masyarakat tidak ingin hal yang sama menimpa anak mereka. Ada keinginan untuk melahirkan generasi yang lebih agamis atau 
memiliki nilai-nilai hidup yang baik mendorong orang tua mencarikan sistem pendidikan alternatif.

Ketiga faktor di atas, sistem pendidikan boarding school seolah menemukan pasarnya. Dari segi sosial, sistem boarding school mengisolasi anak didik dari lingkungan sosial heterogen yang cenderung buruk. Di lingkungan sekolah dan asrama dikonstruksi suatu lingkungan sosial yang relatif homogen yakni teman sebaya dan para guru pembimbing. Homogen dalam tujuan yakni menuntut ilmu sebagai sarana mengejar cita-cita. Dari segi ekonomi, boarding school memberikan layanan yang paripurna sehingga menuntut biaya yang cukup tinggi. Oleh karena itu anak didik akan benar-benar terlayani dengan baik melalui berbagai layanan dan fasilitas.Dari segi semangat religiusitas, boarding school menjanjikan pendidikan yang seimbang antara kebutuhan jasmani dan ruhani, intelektual dan spiritual. Diharapkan akan lahir peserta didik yang tangguh secara keduniaan dengan ilmu dan teknologi, serta siap secara iman dan amal soleh.

Nampaknya, konsep Islamic boarding school menjadi alternatif sebagai model pengembangan pesantren yang akan datang. Pemerintah diharapkan semakin serius dalam mendukung dan mengembangkan konsep pendidikan seperti ini. Sehingga, pesantren menjadi lembaga pendidikan yang maju dan bersaing dalam mengembangkan ilmu pengetahuan dan keterampilan yang berbasis pada nilai-nilai spiritual yang handal.

Mengacu kepada UU Sisdiknas no. 20 tahun 2003 pasal 15 tentang jenis pendidikan bahwa jenis pendidikan mencakup pendidikan umum, kejuruan, akademik, profesi, vokasi, keagamaan, dan khusus. Maka pesantren adalah salah satu jenis pendidikan yang concern di bidang keagamaan. Secara khusus, ketentuan tentang pendidikan keagamaan ini dijelaskan dalam Pasal 30 Undang-Undang Sisdiknas yang menegaskan: (1) Pendidikan keagamaan diselenggarakan oleh Pemerintah dan/atau kelompok masyarakat dari pemeluk agama, sesuai dengan peraturan perundangundangan. (2) Pendidikan keagamaan berfungsi mempersiapkan peserta didik menjadi anggota masyarakat yang memahami dan mengamalkan nilai-nilai ajaran agamanya dan/atau menjadi ahli ilmu agama. (3) Pendidikan keagamaan dapat diselenggarakan pada jalur pendidikan formal, nonformal, dan informal. (4) Pendidikan keagamaan berbentuk pendidikan diniyah, pesantren, dan bentuk lain yang sejenis. Era reformasi dan lahirnya UU Sisdiknas tahun 2003 tersebut, tampaknya membawa angin segar bagi 
pesantren. Pengakuan pemerintah terhadap keberadaan pesantren semakin jelas. Dengan demikian, maka pengembangan pesantren kedepan secara yuridis formal tidak lagi mengalami kesulitan sebagaimana awal munculnya pesantren sampai pada masa penindasan penjajah dan belenggu pada masa orde lama dan orde baru.

\section{SIMPULAN DAN SARAN}

Prinsip pesantren adalah al muhafadzah 'ala al qadim al shalih, wa al akhdzu bi al jadid al ashlah, yaitu tetap memegang tradisi yang positif, dan mengimbangi dengan mengambil hal-hal baru yang positif. Persoalan-persoalan yang berpautan dengan civic values akan bisa dibenahi melalui prinsip-prinsip yang dipegang pesantren selama ini dan tentunya dengan perombakan yang efektif, berdaya guna, serta mampu memberikan kesejajaran sebagai umat manusia (al musawah bain al nas). Pembaharuan di pesantren hendaknya terus dilakukan terutama bidang menejemen, tata kelola bangunan juga harus menjadi perhatian serius sehingga tampak tertata asri, kurikulum pendidikan pesantren, dan berbagai bidang keahlian (bahasa dan life skill). Dengan demikian, pesantren dapat memainkan peran edukatifnya dalam penyediaan sumber daya manusia yang berkarakter dan berkualitas yang terintegrasikan dalam iman, ilmu, dan amal shaleh.

Keberadaan pesantren merupakan patner bagi institusi pemerintah untuk bersama-sama meningkatkan mutu pendidikan yang ada sebagai basis bagi pelaksanaan transformasi sosial melalui penyediaan sumber daya manusia yang qualified dan berakhlakul karimah. Terlebih lagi, proses transformasi sosial di era otonomi, mensyaratkan daerah lebih peka menggali potensi lokal dan kebutuhan masyarakatnya sehingga kemampuan yang ada dapat dioptimalkan. Dengan demikian, maka pesantren bekerja keras untuk memperbaiki segala kekurangannya dan menambah hal-hal yang baru yang menjadi kebutuhan umat sekarang ini. Sebab, model pendidikan pesantren yang mendasarkan diri pada sistem konvensional atau klasik tidak akan banyak membantu dalam penyediaan sumber daya manusia yang memiliki kompetensi integratif baik dalam penguasaan pengetahuan agama, pengetahuan umum dan kecakapan teknologis. 


\section{DAFTAR PUSTAKA}

Asmaun Sahlan. (2013). Pendidikan Karakter dalam Perspektif Islam (Kajian Penerapan Pendidikan Karakter di Lembaga Pendidikan Islam). El-HiKMAH, 9(2), 139-149.

Aulia, M. F., \& Samino. (2015). Pengelolaan Pendidikan Karakter Di Pondok Pesantren Muhammadiyah "Miftakhul "Ulum" Pekajangan Pekalongan." PKn Progresif, 10(1).

Azra, A. (1997). Pesantren: Kontinuitas dan Perubahan, dalam Nurchalish madjid, Bilik-Bilik Pesantren: Sebuah Potret Perjalanan.

Bruinessen, M. Van. (1995). Kitab Kuning Pesantren dan Tarekat. Bandung: Mizan.

Damopolii, M. (2011). Pesantren Modern IMMIM: Pencetak Muslim Modern. Jakarta: Rajawali Pers.

Dhofier, Z. (1982). Tradisi Pesantren: Studi tentang Pandangtan Hidup Kyai. Jakarta: LP3ESW.

Faiqoh, \& Mahfudh, S. (2015). Model Pembentukan Karakter Religius Santri Tahfidz Al-Qur'an di Pondok Pesantren Mathali'ul Huda Pusat Kajen Pati. EDUKASI: Jurnal Peneliti an Pendidikan Agama Dan Keagamaan, 13(3).

Hayati, F. (2011). Pesantren sebagai Alternatif Model Lembaga Pendidikan Kader Bangsa. MIMBAR, XXVII(2), 157-163.

Kartodirjo, S. (1993). Pengantar Sejarah Indonesia Baru: 1500-1900 Dari Emperium Sampai Imperium.

Kuntowijoyo. (1993). Paradigma Islam: Interprestasi Untuk Aksi. Bandung: Mizan.

Kurniawan, A. (2016). Pendidikan Karakter di Pondok Pesantren Dalam Menjawab Krisis Sosial. Edueksos: Jurnal Pendidikan Sosial \& Ekonomi, 4(2).

Madjid, N. (1997). Bilik-Bilik Pesantren sebuah Potret Perjalanan. Jakarta: Paramadina.

Majid, A., \& Andayani, D. (2011). Pendidikan Karakter: perspektif Islam. Bandung: PT. Remaja Rosdakarya.

Makmun, H. A. R. (2014). Pembentukan Karakter Berbasis Pendidikan Pesantren: Studi di Pondok Pesantren Tradisional dan Modern Di Kabupaten Ponorogo. Cendekia Vol., 12(2).

Malik, R, W., \& S, R. (2013). Fungsi Pendidikan Karakter Mengatasi Kenakalaan Remaja Di Lembaga Pemasyarakatan Anak Kelas II B Kecamatan Sungai Raya. Jurnal Pendidikan Dan Pembelajaran, 2(12), 1-11.

Mastuhu. (1994). Dinamika Sistem Pendidikan Pesantren. Jakarta: INIS.

Muslich, M. (2011). Pendidikan Karakter Menjawab Tantangan Krisis 
Multidimensional. Jakarta: Bumi Aksara.

Nizar, S. (2007). Sejarah Pendidikan Islam: Menelusuri Jejak Sejarah Pendidikan Era Rasululloah Sampai Indonesia. Jogjakarta: Prenada Media Group.

Nuryana. (2013). Konsistensi Pendidikan Karakter di Pondok Pesantren Al-Ma'un Desa Kepuh Palimanan Cirebon. Holistik, 14(1).

Prasidjo, S., \& Al, E. (2001). "Profil Pesantren”, dalam Abudin Nata (editor), Sejarah Pertumbuhan dan Perkembangan lembaga-Lembaga Pendidikan Islam di Indonesia. Jakarta: Grasindo.

Proyek Pembangunan Pertanian Rakyat Terpadu Biro Perencanaan, Departemen Pertanian, K. sama dengan P. I. J. (1998). Kajian Landasan Syari'ah, dan Kelembagaan Pemberdayaan Ekonomi Rakyat Melalui Pondok Pesantren. Jakarta.

Purwanti. (2012). Implementasi Pengembangan Karakter Dalam Pembelajaran Di Lembaga Pendidikan Tinggi Kependidikan (LPTK). Jurnal Pendidikan Sosiologi Dan Humaniora, 3(2), 120-131.

Rodliyah, H. St. (2014). Manajemen Pondok Pesantren Berbasis Pendidikan Karakter (Studi Kasus di Pondok Pesantren "Annuriyyah" Kaliwining Kecamatan Rambipuji Kabupaten Jember). Cendekia, 12(2).

Samani, M., \& Hariyanto. (2011). Konsep dan Model Pendidikan Karakter. Remaja Rosda Karya.

Steenbrink, K. A. (1994). Pesantren, Sekolah dan Madrasah, Pendidikan Islam dalam Kurun Modern. Jakarta: LP3ES.

Subekti, M. Y. A. (2015). Pendidikan Karakter di Pondok Pesantren Anak-Anak. TA'LIMUNA, 4(1), 55-72.

Sulaiman, D. (2013). MANAJEMEN PENDIDIKAN PESANTREN MODERN DALAM PEMBENTUKAN KARAKTER ANAK: Studi Kasus pada Pondok Pesantren Modern Diniyyah Pasia Kabupaten Agama. Jurnal Al-Fikrah, I(2).

Suryanegara, A. M. (1998). Menemukan Sejarah Wacana Pergerakan Islam di Indonesia. Bandung: Mizan.

Ubaidillah, A. F. (2016). Pembentukan Karakter Religius dan Mandiri Melalui Model Pendidikan Ala Pondok Pesantren. AL-WIJDÁN: Journal of Islamic Education Studies, I(1), 1-12.

Visi, Misi dan Tradisi UIN Maulana Malik Ibrahim Malang. (2012).

Wahidah, E. Y. (2015). Studi Implementasi Tradisionalisasi dan Modernisasi Pendidikan di Pondok Pesantren. MUADDIB, 5(2), 184-207.

Zarkasyi, A. S. (1998). Langkah Pengembangan Pesantren dalam Rekontruksi Pendidikan dan Tradisi Pesantren Religiusitas Iptek. Yogyakarta: Pustaka Pelajar. 
Ziemek, M. (1986). Pesantren Dalam Perubahan Sosial. Jakarta: P3M.

Zuhriy, M. S. (2011). Budaya Pesantren dan Pendidikan Karakter pada Pondok Pesantren Salaf. Walisongo, 19(2), 287-310. 